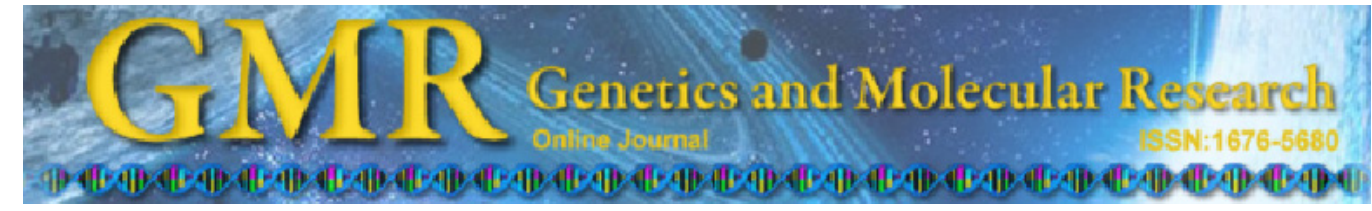

Methodology

\title{
Optimization of DNA extraction from fresh leaf tissues of Melanoxylon brauna (Fabaceae)
}

D.B. Borges ${ }^{1}$, M.B. Amorim ${ }^{1}$, A.M. Waldschmidt ${ }^{1}$, E. Mariano-Neto ${ }^{2}$, C.V. Vivas ${ }^{3}$ and D.G. Pereira ${ }^{4}$

${ }^{1}$ Departamento de Ciências Biológicas, Universidade Estadual do Sudoeste da Bahia, Jequié, BA, Brasil

${ }^{2}$ Departamento de Botânica, Universidade Federal da Bahia,

Salvador, BA, Brasil

${ }^{3}$ Departamento de Ciências Biológicas, Universidade Estadual de Santa Cruz, Ilhéus, BA, Brasil

${ }^{4}$ Departamento de Química e Exatas,

Universidade Estadual do Sudoeste da Bahia, Jequié, BA, Brasil

Corresponding author: D.B. Borges

E-mail: dani_borges88@hotmail.com

Genet. Mol. Res. 11 (2): 1586-1591 (2012)

Received September 2, 2011

Accepted January 17, 2012

Published May 22, 2012

DOI http://dx.doi.org/10.4238/2012.May.22.8

ABSTRACT. Melanoxylon brauna (Fabaceae - Caesalpinioideae) is an
endemic and valuable hardwood tree species in the Brazilian Atlantic
rainforest; it is comparable to African ebony wood. We tested three pro-
tocols of DNA extraction based on the citrimonium bromide (CTAB)
method and evaluated the quantity, purity and integrity of the DNA. We
also determined whether these procedures interfere with PCR amplifi-
cation in order to develop a protocol for $M$. brauna. We found that the
quality and integrity of DNA were improved with the use of proteinase
$\mathrm{K}$ in the extraction buffer and by modifications in the centrifugation
speed. The lowest concentration of DNA was obtained with Doyle and
Doyle's protocol (5.42 ng/ $\mu \mathrm{L}$ ). Ferreira and Grattapaglia's protocol
modified for $M$. brauna provided the most DNA ( $36.89 \mathrm{ng} / \mu \mathrm{L}$ ) and the
highest quality DNA (purity ratio of $1.80 \mathrm{~nm}$ ). The original Ferreira and 
Grattapaglia protocol provided $13.42 \mathrm{ng} / \mu \mathrm{L}$ DNA; however, the purity ratio $(1.44 \mathrm{~nm})$ indicates protein contamination. PCR results showed that Ferreira and Grattapaglia's protocol modified for M. brauna gave satisfactory quantity and purity of DNA for molecular studies.

Key words: Atlantic rainforest; Molecular marker; Endangered species; DNA extraction protocol optimization

\section{INTRODUCTION}

Studies in the Brazilian Atlantic rainforest revealed an increased sensitivity of tree species to fragmentation processes and logging activities. The activities lead to profound changes on the tree communities and cause loss of important species, especially the longlived, shade-tolerant, emergent, and canopy trees, as well as hardwood tress bearing large fruits that are dispersed by vertebrates (Lopes et al., 2009, Pardini et al., 2009).

On the other hand, studies on genetic variability changes in response to habitat modifications are essential for evaluating the impacts over population structure and also species persistence on the long term (Aguilar et al., 2008; Griffen and Drake, 2008).

DNA analysis performed using molecular markers and polymerase chain reaction (PCR) is widely used in studies of genetic diversity, phylogeny, evolution, and population structure. Thus, efficient, fast, and inexpensive DNA extraction protocols are critical to perform molecular ecology studies of endangered species. Most protocols used for DNA extraction from plants use cationic hexadecyltrimethylammonium bromide (CTAB) detergent (Doyle and Doyle, 1990; Ferreira and Grattapaglia, 1998; Romano and Brasileiro, 1999) in different concentrations according to the studied species and tissues used for extraction.

Melanoxylon brauna, popularly known as "brauna", belongs to Fabaceae: Caesalpinioideae; it is an endemic tree from Brazilian Atlantic rainforest found between São Paulo and Bahia in seasonal forests (Oliveira Filho, 2006) and moist forests (Mariano-Neto, 2004). Brauna is widely used for manufacturing external and hydraulic works and musical instruments. Its wood is heavy, compact, hard, and durable (Lorenzi, 2002). Being a hardwood with high market value, brauna was highly exploited by sawmill owners in southern Bahia, Brazil (Mesquita, 1997). It is currently included in the Official List of Endangered Flora of Brazil (IBAMA, 1992).

The objective of this study was to standardize the protocol of genomic DNA extraction from M. brauna for genetic studies by using inter-simple sequence repeat (ISSR) molecular markers.

\section{MATERIAL AND METHODS}

\section{Plant material}

Fresh leaves of M. brauna collected from moist forests of south and southwest Bahia were used. The leaf samples were collected and placed in plastic bags and sent to the Laboratory of Molecular Genetics, UESB, Jequié Campus, where they were washed with distilled water and stored at $-20^{\circ} \mathrm{C}$ until use. 


\section{Protocols}

Three protocols were tested in this study:

1. Doyle and Doyle (1990): extraction buffer consisting of 2\% polyvinylpyrrolidone (PVP), 1.25 M NaCl, 0.1 M Tris-HCl, pH 8.0, $10 \mathrm{mM}$ ethylenediaminetetraacetic acid (EDTA), $2 \% \mathrm{CTAB}$, and $2 \%$ 2-mercaptoethanol.

2. Ferreira and Grattapaglia (1998): extraction buffer consisting of 1\% PVP, $1.4 \mathrm{M}$ $\mathrm{NaCl}, 100$ mM Tris-HCl, pH 8.0, 20 mM EDTA, 2\% CTAB, 2\% 2-mercaptoethanol.

3. Ferreira and Grattapaglia (1998) modified for M. brauna: extraction buffer consisting of 1\% PVP, $1.4 \mathrm{M} \mathrm{NaCl}, 100 \mathrm{mM}$ Tris- $\mathrm{HCl}, \mathrm{pH}$ 8.0, $20 \mathrm{mM}$ EDTA, 2\% CTAB, 2\% 2-mercaptoethanol, $1 \%$ proteinase $\mathrm{K}$.

\section{Procedures}

1. The leaves, previously cut into cubes, were placed in $1.5-\mu \mathrm{L}$ microtubes and hand mashed using a glass pestle. Immediately after maceration, $700 \mu \mathrm{L}$ extraction buffer was added to each microtube.

2. The samples containing fresh leaf tissue were incubated at $65^{\circ} \mathrm{C}$ for $30 \mathrm{~min}$; the microtubes were inverted every $10 \mathrm{~min}$.

3. A volume of $700 \mu \mathrm{L} 24: 1$ chloroform-isoamyl alcohol (v/v) was added for deproteinization; microtubes were inverted 10-20 times for 5 min.

4. The microtubes were centrifuged at $13,000 \mathrm{rpm}$ for $7 \mathrm{~min}$ in a refrigerated microcentrifuge at $4^{\circ} \mathrm{C}$.

5. The aqueous phase was transferred to a new microtube.

6. The nucleic acids were precipitated by adding two-third the volume of cold $95 \%$ isopropanol.

7. Microtubes containing nucleic acids were incubated at $20^{\circ} \mathrm{C}$ for $12 \mathrm{~h}$.

8. The microtubes were centrifuged at $13,000 \mathrm{rpm}$ for $10 \mathrm{~min}$.

9. The supernatant was discarded, and the pellet was washed twice with $1 \mathrm{~mL}$ cold $70 \%$ ethanol and once with cold $90 \%$ ethanol.

10. The pellet was resuspended in $50 \mu \mathrm{L}$ TE buffer.

11. One aliquot of each sample was submitted to electrophoresis on $0.8 \%$ agarose gel containing $0.2 \mu \mathrm{g} / \mathrm{mL}$ ethidium bromide to check the integrity and purity of the extracted DNA.

12. The amount of DNA was measured using spectrophotometry, assuming an equivalency of $50 \mu \mathrm{g} / \mathrm{mL}$ for $1 \mathrm{U}$ absorbance at $260 \mathrm{~nm}$. Quality was evaluated by the ratio $\mathrm{A}_{260} / \mathrm{A}_{280} \mathrm{~nm}$.

13. DNA samples were stored at $-20^{\circ} \mathrm{C}$ for future use.

\section{Amplification and electrophoresis}

Amplification reaction optimization was performed in a PTC-100 thermocycler (MJ Research Inc.). The total volume of each reaction was $25 \mu \mathrm{L}$ containing 50 ng genomic DNA, $200 \mu \mathrm{M}$ dNTPs, $50 \mathrm{pM}$ primer ISSR (Kit UBC), $1.0 \mathrm{U}$ Taq polymerase, and $1 \mathrm{X}$ Taq buffer. Amplification conditions were adjusted according to the methodology proposed by Liu and Wendel (2001). The thermocycler was programmed for one initial denaturation step of $3 \mathrm{~min}$ at $94^{\circ} \mathrm{C}$ and 40 cycles of $1 \mathrm{~min}$ at $92^{\circ} \mathrm{C}$ for denaturation, $2 \mathrm{~min}$ at $53.5^{\circ} \mathrm{C}$ for primer annealing, 
$2 \mathrm{~min}$ at $72^{\circ} \mathrm{C}$ for extension, and 1 step of $7 \mathrm{~min}$ at $72^{\circ} \mathrm{C}$ for the final extension.

The resulting DNA fragments from the amplification were separated by electrophoresis on $1.2 \%$ agarose gel containing $0.20 \mu \mathrm{g} / \mathrm{mL}$ ethidium bromide in $1 \mathrm{X}$ TBE buffer $(90 \mathrm{mM}$ Tris-borate and $1 \mathrm{mM}$ EDTA, pH 8.0). The gels were visualized in UV light and photographed.

\section{RESULTS AND DISCUSSION}

The average DNA concentration varied considerably among the different methods used (Table 1). The Doyle and Doyle (1990) method provided smaller DNA concentration average $(5.42 \mathrm{ng} / \mu \mathrm{L})$ and was the least efficient protocol of DNA extraction from M. brauna. The Ferreira and Grattapaglia (1998) extraction method modified for $M$. brauna provided the largest amount of DNA $(36.89 \mathrm{ng} / \mu \mathrm{L})$ and also presented the best DNA quality (relative purity, $1.80 \mathrm{~nm}$ ). The Ferreira and Grattapaglia (1998) original method also provided satisfactory amount of DNA (13.42 $\mathrm{ng} / \mu \mathrm{L})$; however, the relative purity $(1.44 \mathrm{~nm})$ was not satisfactory. The addition of proteinase K provided DNA samples of superior quality.

Table 1. Quantification and purity of genomic DNA obtained by different extraction protocols, using $50 \mathrm{mg}$ leaf tissue samples of Melanoxylon brauna.

\begin{tabular}{lccc}
\hline Protocols & Quantification $(\mathrm{ng} / \mu \mathrm{L})$ & Total DNA $(\mu \mathrm{g})$ & Ratio $_{\left(\mathrm{A}_{260} / \mathrm{A}_{280} \mathrm{~nm}\right)}$ \\
\hline Doyle and Doyle (1990) & 5.42 & 0.27 & 1.56 \\
Ferreira and Grattapaglia (1998) & 13.42 & 0.67 & 1.44 \\
Ferreira and Grattapaglia (1998) modified for M. brauna & 36.89 & 1.84 & 1.80 \\
\hline
\end{tabular}

According to Barbosa (1998), pure DNA yields a 260/280 nm ratio of 1.8-2.0 nm; a ratio of less than $1.6 \mathrm{~nm}$ indicates contamination with protein and/or other contaminants in excess in the sample, whereas a ratio higher than $2.0 \mathrm{~nm}$ indicates that the samples would be contaminated with chloroform or phenol. In these situations, a reprecipitation of DNA is indicated.

Comparison of agarose gel band patterns (Figure 1) showed that the bands formed by DNA extraction using the Ferreira and Grattapaglia protocol (1998) modified for M. brauna expressed higher quality and quantity of DNA. The bands formed by the DNA obtained by using the Doyle and Doyle (1990) and Ferreira and Grattapaglia (1998) protocols were less clear and had lower amount of DNA showing vertical drag, indicating that the DNA was not intact.
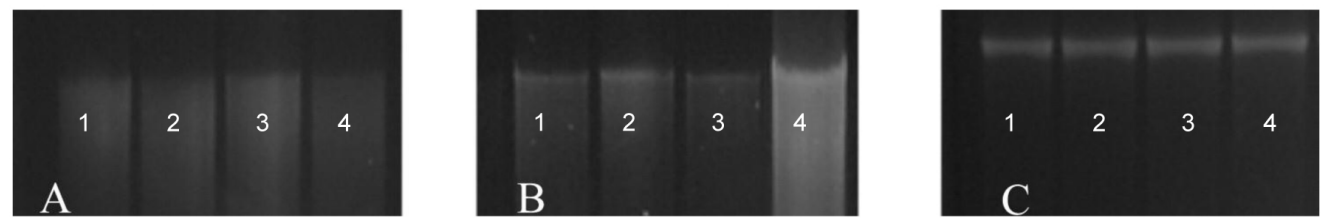

Figure 1. Genomic DNA extracted from specimens of Melanoxylon brauna (lanes 1-4), using protocols (A) Doyle and Doyle (1990), (B) Ferreira and Grattapaglia (1998) and (C) Ferreira and Grattapaglia (1998) modified for M. brauna. 
Comparing the results obtained in this study with those described in the literature is difficult because, although DNA extractions follow standard protocols, alterations to a standardized protocol for the used species are a common occurrence. In addition, the amount of DNA obtained remains very similar among different species. According to Ferreira and Grattapaglia (1998), obtaining concentrations of 10-200 ng/mL from 50-200 mg leaf tissue is possible by using the CTAB method. In this study, the average value of quantification for the Ferreira and Grattapaglia (1998) protocol modified for M. brauna was $36.89 \mathrm{ng} / \mathrm{mL}$ from 50 $\mathrm{mg}$ leaf tissue, suggesting the efficiency of the suggested protocol.

Similar results were obtained by other authors who used optimizing protocols for extracting DNA from legume by using the CTAB method for ensuring purity and quantity. Chiari et al. (2009) obtained 13.30-15.84 $\mu \mathrm{g}$ DNA from $300 \mathrm{mg}$ lead tissue of Stylosanthes guianensis, with purity ratios from 1.40 to $1.50 \mathrm{~nm}$. Ginwal and Mawrya (2009) successfully optimized the CTAB protocol for extracting DNA from Dalbergia sissoo and obtained significant DNA amounts with purity ratios of $1.71-1.90 \mathrm{~nm}$.

Amplification tests revealed that DNA obtained using the protocols of Doyle and Doyle (1990), Ferreira and Grattapaglia (1998), and Ferreira and Grattapaglia (1998) modified for $M$. brauna efficiently amplified primers ISSR UBC-836 and UBC-864 (Figure 2). The differences in quantity and quality of extracted DNA did not interfere with the general patterns of amplification.
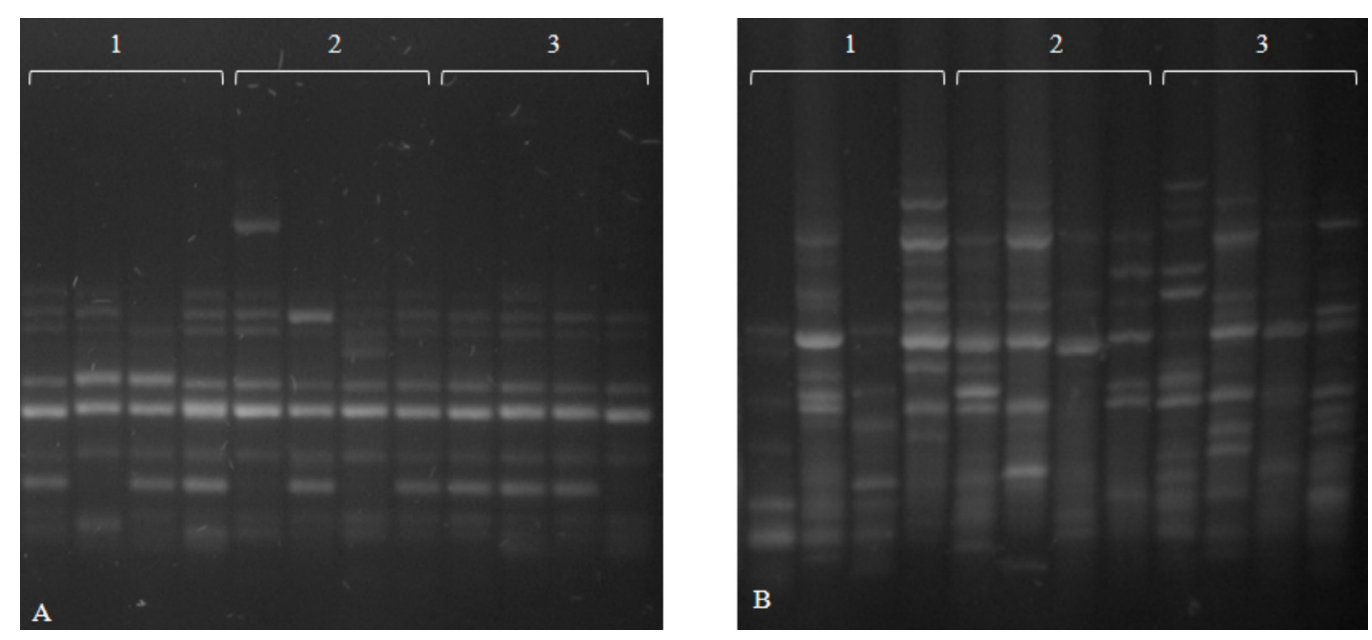

Figure 2. Standard ISSR bands generated with primers (A) U-836 and (B) U-864. Lane 1 = Doyle and Doyle (1990) protocol; lane 2 = Ferreira and Grattapaglia (1998) protocol; lane 3 = Ferreira and Grattapaglia (1998) modified for M. brauna protocol.

The Ferreira and Grattapaglia (1998) protocol modified for M. brauna allowed DNA extraction from brauna's leaf tissue with satisfactory amount and quality for amplification by using PCR-ISSR. This method might be used for molecular ecology studies of the species.

\section{ACKNOWLEDGMENTS}

The authors thank CNPq and UESB for the scholarships granted and Biologia, Genética e Melhoramento Vegetal Research Group for the support. 


\section{REFERENCES}

Aguilar R, Quesada M, Ashworth L, Herrerias-Diego Y, et al. (2008). Genetic consequences of habitat fragmentation in plant populations: susceptible signals in plant traits and methodological approaches. Mol. Ecol. 17: 5177-5188.

Barbosa MM (1998). Quantificação e Controle da Qualidade do DNA Genômico. In: Marcadores Moleculares em Plantas (Milach S, ed.). UFRGS, Porto Alegre, 99-106.

Chiari L, Valle JVR and Resende RMS (2009). Comparação de três métodos de extração de DNA genômico para análises moleculares em Stylosanthes guianensis. Circular Técnica 36: 1-6.

Doyle JJ and Doyle JL (1990). Isolation of plant DNA from fresh tissue. Focus 12: 13-15.

Ferreira ME and Grattapaglia D (1998). Introdução ao Uso de Marcadores Moleculares em Análise Genética. 3a ed. Embrapa-Cenargen, Brasília.

Ginwal HS and Mawrya SS (2009). Evaluation and optimization of DNA extraction method for Dalbergia sissoo leaf. Indian J. Biotechnol. 9: 69-73.

Griffen BD and Drake JM (2008). A review of extinction in experimental populations. J. Anim. Ecol. 77: 1274-1287.

IBAMA (1992). Lista Oficial de Flora Ameaçada de Extinção. IBAMA, Brasil.

Liu B and Wendel JF (2001). Inter simple sequence repeat (ISSR) polymorphisms as a genetic marker system in cotton. Mol. Ecol. Notes 1: 205-208.

Lopes AV, Girão LC, Santos BA and Peres CA (2009). Long-term erosion of tree reproductive trait diversity in edgedominated Atlantic Forest fragments. Biol. Conserv. 142: 1154-1165.

Lorenzi H (2002). Árvores Brasileiras: Manual de Identificação e Cultivo de Plantas Arbóreas do Brasil. 4⿳亠 ed. Instituto Plantarum, Odessa.

Mariano-Neto E (2004). Efeitos da Fragmentação Sobre Comunidades Arbustivo-Arbóreas em Mata Atlântica, Una-BA. Doctoral thesis, USP, São Paulo.

Mesquita CAB (1997). Exploração Madeireira no Sul da Bahia: Situação Atual e Perspectivas. Revista dos Mestrandos em Direito Econômico da UFBA. Edição Especial de Direito Ambiental, 121-135.

Oliveira-Filho AT (2006). Catálogo das Árvores Nativas de Minas Gerais: Mapeamento e Inventário da Flora Nativa e dos Reflorestamentos de Minas Gerais. UFLA, Lavras.

Pardini R, Faria D, Accacio GM and Laps RR (2009). The challenge of maintaining Atlantic forest biodiversity: a multitaxa conservation assessment of an agro-forestry mosaic in southern Bahia. Biol. Conserv. 142: 1178-1190.

Romano E and Brasileiro ACM (1999). Extração de DNA de plantas: soluções para problemas comumente encontrados. Biotecnol. Cienc. Desenvolv. 9: 40-43. 